J. Lake Sci. (湖泊科学), 2019, 31(1): 28-38

DOI 10. 18307/2019. 0103

(c) 2019 by Journal of Lake Sciences

\title{
三峡水库区间来沙量估算及水库排沙效果分析”
}

\author{
刘尚武 ${ }^{1}$, 张小峰 $^{1 * *}$, 许全喜 ${ }^{2}$, 张欧阳 ${ }^{2}$, , $^{\text {俊健 }}{ }^{1}$ \\ (1:武汉大学水资源与水电工程科学国家重点实验室,武汉 430072) \\ $(2$ : 长江水利委员会水文局, 武汉 430010$)$
}

\begin{abstract}
摘 要: 三峡水库是控制和开发长江的重要工程, 具有巨大的防洪、发电、航运等综合效益. 水库排沙比是反映水库拦截 泥沙程度的重要指标. 针对目前三峡水库排沙比计算没有考虑三峡水库区间来沙,结果偏大的问题,依据三峡水库区间 水文站 2003-2016 年实测水文资料, 采用水文学法估算了三峡水库区间月、年人库输沙量, 分析了三峡水库排沙效果及 主要影响因素. 结果表明:1) 三峡水库区间年均来沙量约 $1775 \times 10^{4} \mathrm{t}$, 占总人库沙量的 $10.3 \%$, 近年来沙占比有所增大, 其 中 2013-2016 年来沙量占总人库沙量的 $26.9 \% ; 2$ 三峡水库年均排沙比为 $21.6 \%$, 其中围堰蓄水期为 $34.1 \%$, 初期蓄水期 为 $17.0 \%$,试验性蓄水期为 $15.4 \%$; 3 三峡水库采用“蓄清排浑” 方式运行, 主汛期 7-9 月的排沙比一般大于枯季,但 2013 年以后, 出现了主汛期排沙比小于枯季的现象; 4) 人库细颗粒泥沙的排沙比大于粗颗粒泥沙, 其中粒径 $\mathrm{d} \leqslant 0.062 \mathrm{~mm}$ 的细颗粒泥沙排沙比为 $23.4 \%, 0.062 \mathrm{~mm}<\mathrm{d} \leqslant 0.125 \mathrm{~mm}$ 和 $\mathrm{d}>0.125 \mathrm{~mm}$ 的中粗沙排沙比分别为 $5.5 \%$ 和 $11.1 \% ; 5$ ) 三峡水 库排沙比汛期主要受 $V / Q$ 影响, 枯季主要受人库含沙量的影响; 当 $V / Q$ 约为 $170 \times 10^{4} \mathrm{~s}$ 时, 水库排沙效果最差; 分别建立 了汛期和枯季排沙比经验计算式. 本文的研究成果可为三峡水库水沙优化调度等提供参考.
\end{abstract}

关键词: 悬移质,排沙比; 来沙量; 三峡水库区间

\section{Estimation of sediment amount from ungauged area and analysis of sediment delivery ra- tio of Three Gorges Reservoir}

\author{
LIU Shangwu ${ }^{1}$, ZHANG Xiaofeng ${ }^{1 * *}$, XU Quanxi $^{2}$, ZHANG Ouyang ${ }^{2} \&$ HUANG Junjian ${ }^{1}$ \\ (1: State Key Laboratory of Water Resource and Hydropower Engineering Science, Wuhan University, Wuhan 430072, P.R. \\ China) \\ (2: Bureau of Hydrology, Changjiang Water Resource Commission, Wuhan 430010, P.R. China)
}

\begin{abstract}
The Three Gorges Reservoir with huge comprehensive benefits of flood controlling, power generation and navigation is an important project for Yangtze River. The sediment delivery rate is also an important index for the degree of intercepting sediment in a reservoir. In the view of the current research of sediment delivery ratio without consideration of the sediment from the ungauged area, at present, the result of calculation was larger than that of reality. On the basis of the measured hydrological data of the Three Gorges Reservoir area hydrological station from 2003 to 2016, the amount of sediment from ungauged area was calculated by the hydrological method. Meanwhile, the sediment delivery rates and main influencing factors were analyzed. The results were shown as follows: 1) the annual average sediment yield of the ungauged area was about $1775 \times 10^{4} \mathrm{t}$, accounting for $10.3 \%$ of the total annual average sediment yield of the Three Gorges Reservoir. In recent year, the ratio of sediment from the ungauged area has increased, and that of annual average was $26.9 \%$ from 2013 to 2016. 2) The annual sediment discharge ratio of the Three Gorges reservoir was $21.6 \%$, and $34.1 \%$ in the cofferdam storage period, $17.0 \%$ in the initial storage period, $15.4 \%$ in the experimental water storage period. 3 ) Because the operation of the Three Gorges Reservoir is "store clear and discharge muddy water" , the sediment delivery rate of 7-9 mouths in main flood season is generally greater than that of the dry season. But after 2013 , the sediment delivery rate of main flood season is less than that of the dry season. 4) The sediment delivery ratio of the fine sediment in the reservoir was larger than the coarse sediment, and the sediment delivery ratio of the particle size $\mathrm{d} \leqslant 0.062 \mathrm{~mm}, 0.062 \mathrm{~mm}<\mathrm{d} \leqslant 0.125$
\end{abstract}

* 国家重点研发计划项目(2016YFA0600901) 资助. 2018-05-07 收稿; 2018-06-28 收修改稿. 刘尚武( 1994 ), 男, 硕士研究生;E-mail:502870518@ qq.com.

** 通信作者;E-mail:zhangxfwuhee@ 263.net. 
$\mathrm{mm}$ and $\mathrm{d}>0.125 \mathrm{~mm}$ was $23.4 \%, 5.5 \%$ and $11 \%$, respectively. 5) The main affecting factor of sediment delivery rate in flood season was $V / Q$, but that in dry season was sediment content. When $V / Q$ was about $170 \times 10^{4} \mathrm{~s}$, the effect of sediment delivery in the Three Gorges Reservoir was the worst. At last, the empirical formula of sediment delivery rate of the Three Gorges Reservoir was established for flood season and dry season, respectively. The result of this paper could provide reference for optimal operation of water and sediment in the Three Gorges Reservoir. The results of this paper can provide reference for optimal operation of water and sediment in the Three Gorges Reservoir.

Keywords: Suspended sediment; sediment delivery ratio; sediment yield; the ungauged area of the Three Gorges Reservoir

河流输沙变化作为全球变化研究的重要课题之一,近年来已受到国内外众多学者广泛关注. 目前, 世界 上大多数河流输沙量呈减小趋势, 大型水利工程的建设是导致这一现象的重要原因 ${ }^{[1-2]}$. 三峡水库是控制和 开发长江的重要工程,具有巨大的防洪、发电、航运等综合效益. 水库蓄水后,将不可避免地引起库区泥沙淤 积和坝下游河床冲刷问题,给防洪、航运、生态环境等带来一系列影响. 在三峡工程可行性论证、初步设计、 技术设计以及后续规划等阶段,都将泥沙问题列为需解决的关键问题之一 ${ }^{[3]}$. 水库排沙比是反映水库拦截 泥沙程度的重要指标. 长江科学院和中国水利水电科学研究院曾采用数学模型预测了三峡水库的排沙

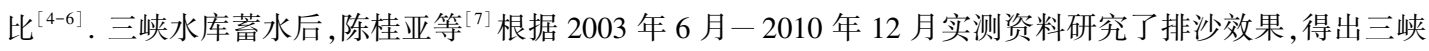
水库年均排沙比为 $26.1 \%$, 其中汛期 5-10 月排沙比为 $29.0 \%$, 略小于数学模型预测值. Yang 等 ${ }^{[8]}$ 认为, 近 年来三峡水库排沙减少主要与近期水文条件的变化有关. 黄仁勇等 ${ }^{[9]}$ 选取了三峡水库蓄水以来 34 场次的 洪水资料, 认为 $V / Q$ 是影响水库排沙的主要因素 ( $Q$ 为人库流量, $V$ 为库容) ; 董占地等 ${ }^{[10]}$ 研究了三峡水库 排沙比对来水来沙的响应, 认为坝前水位和人库、出库流量是主要影响因素, 其次是人库沙量和泥沙粒径大 小. 由于上述排沙比计算成果均未考虑三峡水库区间来沙,存在较实际排沙比偏大的问题. 近年来, 随着金 沙江向家坝、溪洛渡等电站蓄水, 长江上游来沙骤减, 三峡水库区间来沙权重相对增大, 如果不考虑这部分 区间来沙,计算的排沙比将会产生更大的偏差. 三峡水库区间支流众多,很多支流无泥沙观测资料, 即使部 分水文站有泥沙测验资料, 也位于支流的中上游, 无法通过各支流输沙量相加的方法来估算来沙量, 故至今 三峡水库区间鲜见有定量的月、年来沙量估算成果. 本文通过收集三峡水库区间水文站 2003-2016 年实测 水文资料, 采用水文学方法估算了三峡水库区间人库月、年来沙量, 在此基础上, 结合三峡进出库控制站实 测资料, 进一步分析了三峡水库排沙效果和主要影响因素, 提出了三峡水库最不利排沙条件, 建立了水库汛 期和非汛期排沙比经验计算式. 本文的研究成果可为三峡水库水沙优化调度等提供参考.

\section{1 研究区域概况及基本资料}

\section{1 研究区域概况}

三峡水库区间流域水系发育, 是长江流域主要产沙区之一. 两岸支流分布不均, 主要集中在左岸. 流域 面积 $100 \mathrm{~km}^{2}$ 以上的一级支流共有 44 条, 其中嘉陵江是左岸最大的一级支流, 流域面积约 $16 \times 10^{4} \mathrm{~km}^{2}$, 乌江 是右岸最大的一级支流,流域面积 $8.79 \times 10^{4} \mathrm{~km}^{2}$. 主要水系分布见图 1 .

自 2003 年 6 月蓄水运行至 2016 年底, 三峡水库已经历了围堰蓄水期 ( 2003 年 6 月 -2006 年 8 月)、初 期运行期 (2006 年 9 月- 2008 年 9 月)、试验性蓄水期 (2008 年 10 月- 2016 年 12 月) 3 个阶段. 各阶段因回 水末端不同, 故人库控制站不同. 围堰蓄水期, 水库回水末端位于涪陵附近, 人库控制站为长江清溪场站, 三 峡水库区间流域面积约 $4.0 \times 10^{4} \mathrm{~km}^{2}$; 初期运行期水库回水末端位于铜锣峡附近, 人库控制站为长江寸滩站 和乌江武隆站, 区间流域面积约 $5.6 \times 10^{4} \mathrm{~km}^{2}$; 试验性蓄水期水库回水末端位于江津附近, 人库控制站为长江 朱沱站、嘉陵江北碚和乌江武隆站, 区间流域面积约 $7.1 \times 10^{4} \mathrm{~km}^{2}$.三峡出库站为长江黄陵庙站.

\section{2 基本资料}

三峡出、入库控制站水沙资料均选自长江水利委员会水文局历年水文整编成果.

三峡水库区间支流较多,水文监测资料较少且不连续,本次收集了 2003 年以来有较完整记录的 13 个水 文站资料,测站基本情况见图 1 和表 1. 香溪河兴山站有流量、泥沙资料, 但 2011 年起停测, 分别在香溪河上 游设立了南阳站和古夫站, 其中南阳站测有流量和泥沙, 古夫站仅测有流量, 鉴于南阳站、古夫站的流域面 积之和与兴山站相差较小,故兴山站的流量采用南阳站、古夫站流量合成的方法推算. 
降水资料来源于重庆市水文局、湖北省水文局、国家气象中心的雨量相关整编成果.

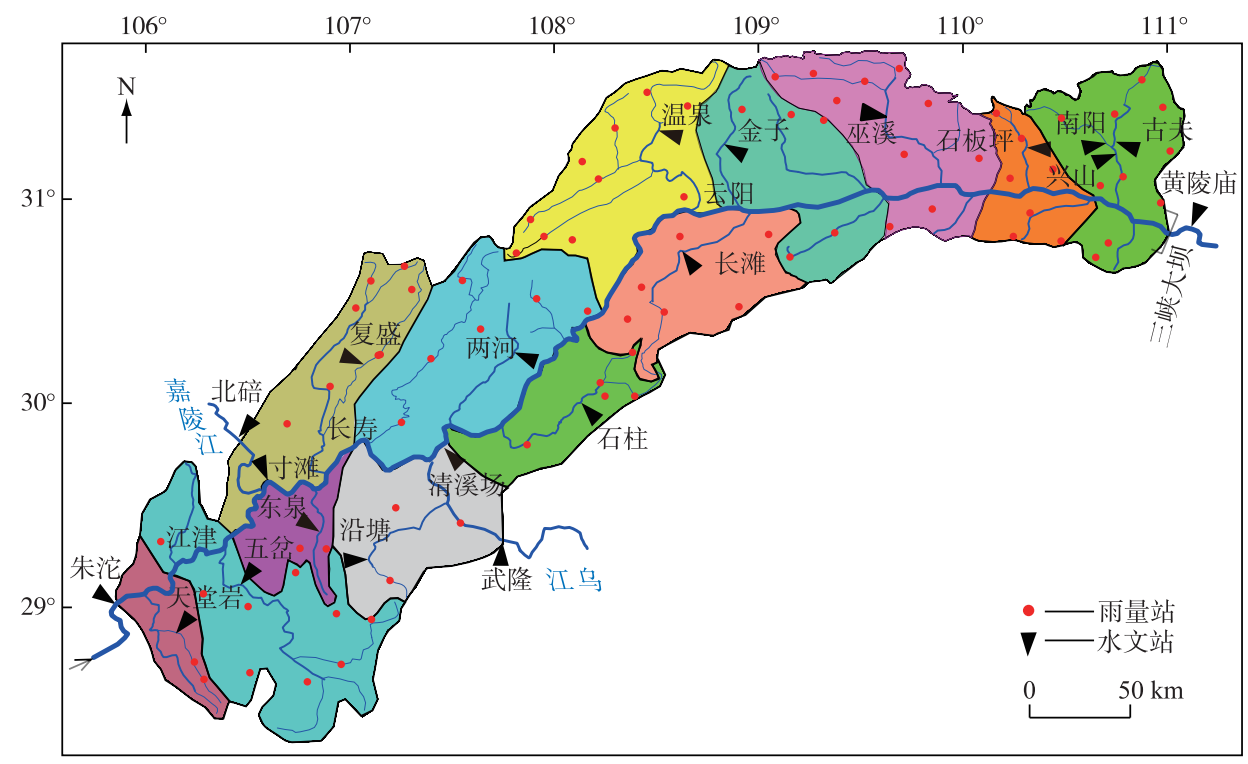

图 1 三峡水库库区水系、站网布置及分区

Fig.1 Layout and distribution of water system and station network in the Three Gorges Reservoir area

表 1 三峡水库区间支流水文站基本情况

Tab. 1 The basic situation of water station in the Three Gorges Reservoir area

\begin{tabular}{|c|c|c|c|c|c|c|}
\hline 序号 & 站名 & 所在河流 & 控制流域面积 $/ \mathrm{km}^{2}$ & 管理单位 & 设站时间 & 主要测量项目 \\
\hline \multirow[t]{3}{*}{1} & 兴山 & 香溪河 & 1851 & 湖北省水文局 & 1958 年, 2011 年停测 & 流量、沙 \\
\hline & 南阳 & 香溪河 & 672 & 湖北省水文局 & 2008 年 & 流量、沙 \\
\hline & 古夫 & 香溪河 & 1167 & 湖北省水文局 & 2008 年 & 流量 \\
\hline 2 & 石板坪 & 沿渡河 & 466 & 湖北省水文局 & 1997 年 & 流量 \\
\hline 3 & 巫溪 & 大宁河 & 2001 & 长江委水文局 & 1972 年 & 流量、沙 \\
\hline 4 & 金子 & 汤溪河 & 711 & 重庆市水文局 & 2002 年 & 流量、沙 \\
\hline 5 & 长滩 & 磨刀溪 & 2034 & 重庆市水文局 & 2001 年 & 流量、沙 \\
\hline 6 & 温泉 & 小江 & 1158 & 重庆市水文局 & 2002 年 & 流量、沙 \\
\hline 7 & 石柱 & 龙河 & 898 & 重庆市水文局 & 1959 年 & 流量、沙 \\
\hline 8 & 两河 & 渠溪河 & 157 & 重庆市水文局 & 1958 年 & 流量、沙 \\
\hline 9 & 沿塘 & 鸭江 & 599 & 重庆市水文局 & 2002 年 & 流量 \\
\hline 10 & 复盛 & 御临河 & 1153 & 重庆市水文局 & 1962 年 & 流量 \\
\hline 11 & 东泉 & 五布河 & 489 & 重庆市水文局 & 1958 年 & 流量 \\
\hline 12 & 五岔 & 綦江 & 5566 & 重庆市水文局 & 1940 年 & 流量、沙 \\
\hline 13 & 天堂岩 & 狮头河 & 350 & 四川省水文局 & 1958 年 & 流量 \\
\hline
\end{tabular}

\section{2 研究方法}

\section{1 区间来沙量和径流量估算}

首先根据流域地质、地貌、降雨分布等情况, 将三峡水库区间流域划分为若干个区域,然后根据实测水 文资料和降水资料, 分别计算各区域的来沙量和径流量, 最后将各区域计算成果相加, 即可得到整个三峡水 库区间的来沙量和径流量. 
2.1.1 区域划分 根据三峡水库区间现有水文站的分布情况,结合三峡地质、地貌等下垫面特征和降雨分布 情况, 并尽量满足水文比拟法要求为原则, 将三峡水库区间流域划分为若干个区域. 按上述原则, 将试验性 蓄水期的三峡水库区间划分为 13 个区域(图 1), 初期运行期划分为 11 个区域(图略), 围堰蓄水期划分为 8 个区域(图略). 各区域基本情况见表 2. 不同蓄水期的各区域面积除在回水末端附近有变化外,其他区域保 持不变.

表 2 三峡水库各区域基本情况

Tab.2 The basic situation of each section of the Three Gorges Reservoir

\begin{tabular}{|c|c|c|c|c|c|c|}
\hline \multirow{2}{*}{ 序号 } & \multicolumn{3}{|c|}{ 区域面积 $/ \mathrm{km}^{2}$} & \multirow{2}{*}{ 主要河流 } & \multirow{2}{*}{ 地貌情况 } & \multirow{2}{*}{ 代表性水文站 } \\
\hline & 围堰蓄水期 & 初期蓄水期 & 试验蓄水期 & & & \\
\hline 1 & 5474 & 5474 & 5474 & 香溪河 & 山地 & 兴山 \\
\hline 2 & 2821 & 2821 & 2821 & 沿渡河 & 山地 & 南阳 \\
\hline 3 & 6617 & 6617 & 6617 & 大宁河 & 山地 & 古夫 \\
\hline 4 & 6439 & 6439 & 6439 & 汤溪河、梅溪河 & 山地 & 金子 \\
\hline 5 & 5590 & 5590 & 5590 & 磨刀溪 & 山地 & 长滩 \\
\hline 6 & 6939 & 6939 & 6939 & 小江 & 丘陵、山地 & 温泉 \\
\hline 7 & 3867 & 3867 & 3867 & 龙河 & 丘陵、山地 & 石柱 \\
\hline 8 & 2751 & 8414 & 8414 & 渠溪河、龙溪河 & 丘陵 & 两河 \\
\hline 9 & & 5442 & 5442 & 鸭江 & 丘陵、山地 & 沿塘 \\
\hline 10 & & 3678 & 6114 & 御临河 & 丘陵 & 复盛 \\
\hline 11 & & 1176 & 2380 & 五布河 & 丘陵 & 东泉 \\
\hline 12 & & & 8369 & 綦江 & 丘陵、山地 & 五岔 \\
\hline 13 & & & 2288 & 狮头河 & 丘陵 & 天堂岩 \\
\hline 合计 & 40498 & 56457 & 70754 & & & \\
\hline
\end{tabular}

2.1.2 区域月、年来沙量计算 设区域 $j$ 所在水文站第 $i$ 月单位面积月平均输沙率为 $g_{b j, i}$ (相当于单位时间月 输沙模数), 假定区域 $j$ 各位置的单位面积月平均输沙率相同, 则区域 $j$ 第 $i$ 月的月输沙量 $W_{j, i}$ 为:

$$
W_{j, i}=g_{b j, i} \cdot A_{j} \cdot \Delta t_{i}=\frac{G_{b j, i}}{a_{j}} \cdot A_{j} \cdot \Delta t_{i}
$$

式中, $A_{j}$ 为区域 $j$ 的面积 $\left(\mathrm{km}^{2}\right) ; a_{j}$ 为区域 $j$ 所在水文站的控制面积 $\left(\mathrm{km}^{2}\right) ; G_{b j, i}$ 为区域 $j$ 内水文站第 $i$ 月月 平均输沙率 $(\mathrm{kg} / \mathrm{s})$, 当区域 $j$ 的水文站有实测泥沙资料时, $G_{b j, i}$ 为实测值; $\Delta t_{i}$ 为第 $i$ 月的时间 $(\mathrm{s})$.

当区域 $j$ 的水文站无实测泥沙资料时, 区域 $\mathrm{j}$ 第 $\mathrm{i}$ 月的输沙率 $G_{b j, i}$ 借用相似流域的流量与输沙率关系, 以实测流量计算. 为分析三峡水库区间不同区域水文站流量与输沙率关系变化规律, 点绘了有实测泥沙资 料的 8 个水文站单位面积月平均输沙率 $g_{b j, i}$ 和单位面积月平均流量 $q_{j, i}$ 相关关系图 (图 2). 由图 2 可见, 各 站虽然控制的流域面积大小不同, 条件各异,但点群较为集中, 相关性较好, 且各站无明显系统偏离, 可用该 关系结合该区域水文站实测月平均流量来估算三峡水库区间未测泥沙区域的输沙量,其关系式为:

$$
\begin{gathered}
g_{b j, i}=290 q_{j, i}^{3.22} \\
q_{j, i}=\frac{Q_{j, i}}{a_{j}}
\end{gathered}
$$

式中, $Q_{j, i}$ 为区域 $j$ 内水文站第 $i$ 月实测月平均流量 $\left(\mathrm{m}^{3} / \mathrm{s}\right)$, 其余符号同前.

将水文站实测月平均流量 $Q_{j, i}$ 代人公式 (2)、(3) 计算单位面积月平均输沙率为 $g_{b j, i}$, 然后用公式(1) 即 可计算出未测区域的逐月输沙量.

三峡水库区间第 $i$ 月的输沙量 $W_{\text {区 }, i}$ 为:

$$
W_{\text {区, } i}=\sum_{j=1}^{n} W_{j, i}
$$

式中, $n$ 为分区数, 试验性蓄水期 $n=13$, 初期运行期 $n=11$, 围堰蓄水期 $n=8$. 


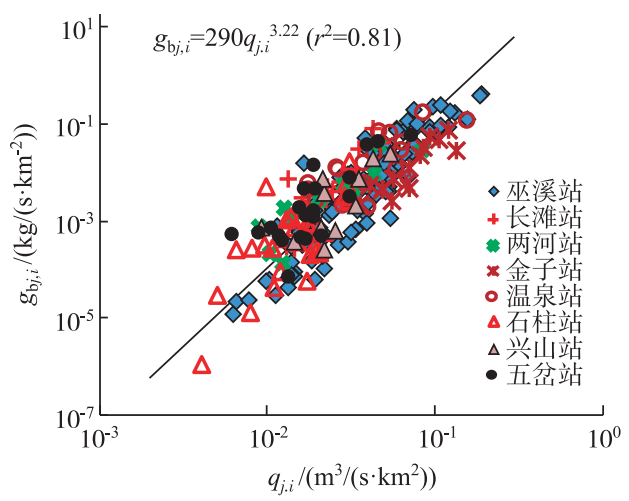

图 2 各站 $g_{\mathrm{b} j, i}$ 与 $q_{j, i}$ 的相关关系

Fig.2 Correlative relationship between $g_{\mathrm{bj}, i}$ and $q_{j, i}$ of different hydrological stations

三峡水库区间年输沙量 $W_{\text {区 }}$ 为:

$$
W_{区}=\sum_{i=1}^{12} W_{\text {区 }, i}
$$

2.1.3 区域月、年径流量计算 各区域的月径流量采用各自区域代表水文站的月径流量通过面积缩放和雨量 修正计算. 区域 $j$ 第 $i$ 月的径流量 $R_{j, i}$ 的计算公式为:

$$
R_{j, i}=Q_{j, i} \cdot \frac{A_{j}}{a_{j}} \cdot \frac{\bar{P}_{j, i}}{\overline{\bar{p}}_{j, i}} \cdot \Delta t_{i}
$$

式中, $\bar{p}_{j, i}$ 和 $\bar{P}_{j, i}$ 分别为区域 $j$ 和水文站第 $i$ 月的算数平均面雨量 $(\mathrm{mm})$, 其余符号同前.

三峡水库区间月、年径流量参照上述月、年输沙量方法计算.

\section{2 三峡水库排沙比和入库含沙量计算}

三峡水库各月的排沙比 $\eta_{i}$ 等于黄陵庙站月输沙量与三峡总人库月输沙量之比,计算公式为:

$$
\eta_{i}=\frac{W_{\text {黄 }, i}}{\left(W_{区, i}+W_{\text {控 }, i}\right)}
$$

式中, $W_{\text {黄, } i}$ 为黄陵庙站某年第 $i$ 月的输沙量 $\left(10^{4} \mathrm{t}\right) ; W_{\text {控, } i}$ 为三峡人库控制站第 $i$ 月的输沙量 $\left(10^{4} \mathrm{t}\right)$, 其余符 号同前.

三峡水库月平均人库含沙量 $s_{i}$ 等于第 $i$ 月的总人库输沙量与总人库径流量之比,计算公式为:

$$
s_{i}=\frac{\left(W_{\text {区 }, i}+W_{\text {控 }, i}\right)}{\left(R_{\text {区 }, i}+R_{\text {控 }, i}\right)}
$$

式中, $s_{i}$ 单位为 $\mathrm{kg} / \mathrm{m}^{3} ; R_{\text {区 }, i 、} R_{\text {控 }, i}$ 分别为三峡水库区间和人库控制站第 $i$ 月的径流量, 其余符号同前.

\section{3 结果与分析}

\section{1 三峡水库区间入库输沙量、径流量成果}

3.1 .1 估算成果 由表 3 可见, 三峡水库蓄水以来, 三峡水库区间流域总人库沙量为 $24081 \times 10^{4} \mathrm{t}$, 其年人库 来沙量在 $900 \times 10^{4} \sim 3100 \times 10^{4} \mathrm{t}$ 之间变化, 年均 $1775 \times 10^{4} \mathrm{t}$, 占总人库输沙量的 $10.3 \%$, 年内区间来沙主要集 中在 6-9 月,约占年总量的 $83.6 \%$, 其中 $1-3$ 月、 $11-12$ 月来沙量较少, 仅约占年总量的 $1.0 \% ; 2013$ 年后 金沙江向家坝、溪洛渡电站蓄水, 长江上游来沙大幅减少, 三峡水库区间来沙占比增大, 由 2003-2012 年的 年均占比 $8.5 \%$ 增大到 2013-2016 年的 26.9\%, 说明三峡水库区间来沙量是不应忽视的. 三峡水库区间人库 年径流量变化在 $175 \times 10^{8} \sim 620 \times 10^{8} \mathrm{~m}^{3}$ 之间, 年均 $346 \times 10^{8} \mathrm{~m}^{3}$, 占总人库径流量的 $8.2 \%$, 年内区间来流主要 集中在 5-10 月,占约年总量的 $75.6 \%$,其中 6-9 月占年总量的 $56.8 \%$. 
表 3 三峡水库蓄水以来来水来沙量

Tab.3 Water and sediment into the Three Gorges Reservoir

\begin{tabular}{|c|c|c|c|c|c|c|c|}
\hline \multirow{2}{*}{ 时间 } & \multicolumn{2}{|c|}{ 人库输沙量/ $\left(\times 10^{4} \mathrm{t}\right)$} & \multirow{2}{*}{$\begin{array}{l}\text { 区间占总人库 } \\
\text { 输沙量比例/\% }\end{array}$} & \multicolumn{2}{|c|}{ 人库径流量 $/\left(\times 10^{8} \mathrm{~m}^{3}\right)$} & \multirow{2}{*}{$\begin{array}{l}\text { 区间占总人库 } \\
\text { 径流量比例/\% }\end{array}$} & \multirow{2}{*}{$\frac{\text { 出库沙量 } /\left(\times 10^{4} \mathrm{t}\right)}{\text { 黄陵庙站 }}$} \\
\hline & 区间 & 控制站 & & 区间 & 控制站 & & \\
\hline 2003 年 $6-12$ 月 & 1538 & 20811 & 6.9 & 177 & 3254 & 3.8 & 8399 \\
\hline 2004 年 & 1679 & 16600 & 9.2 & 229 & 3898 & 5.5 & 6370 \\
\hline 2005 年 & 1671 & 25400 & 6.2 & 293 & 4297 & 6.4 & 10300 \\
\hline 2006 年 & 901 & 10207 & 8.1 & 175 & 2790 & 2.6 & 891 \\
\hline 2007 年 & 3001 & 22047 & 12.0 & 338 & 3649 & 8.5 & 5090 \\
\hline 2008 年 & 1561 & 21779 & 6.7 & 365 & 3877 & 7.3 & 3220 \\
\hline 2009 年 & 1382 & 18300 & 7.0 & 353 & 3464 & 9.2 & 3600 \\
\hline 2010 年 & 1689 & 22900 & 6.9 & 316 & 3722 & 7.8 & 3280 \\
\hline 2011 年 & 2231 & 10200 & 17.9 & 376 & 3015 & 11.1 & 692 \\
\hline 2012 年 & 1061 & 21900 & 4.6 & 477 & 4166 & 10.3 & 4530 \\
\hline 2013 年 & 1876 & 12700 & 12.9 & 350 & 3345 & 9.5 & 3280 \\
\hline 2014 年 & 3071 & 5540 & 35.7 & 616 & 3820 & 13.9 & 1050 \\
\hline 2015 年 & 1140 & 3200 & 26.3 & 459 & 3358 & 12.0 & 425 \\
\hline 2016 年 & 2050 & 4220 & 32.7 & 536 & 3719 & 12.6 & 884 \\
\hline 平均 & 1775 & 15415 & 10.3 & 346 & 3898 & 8.2 & 3715 \\
\hline
\end{tabular}

3.1 .2 成果合理性分析 长江科学院基于遥感影像,采用土壤侵蚀量法估算的 2007 、2010 年三峡水库区间人 库沙量分别为 $2415 \times 10^{4}$ 和 $1009 \times 10^{4} \mathrm{t}^{[11]}$, 本文估算的这两年来沙量分别为 $3001 \times 10^{4}$ 和 $1689 \times 10^{4} \mathrm{t}$, 两者差 别不大; 长江水利委员会水文局对三峡水库寸滩至宜昌区间的来沙量进行了估算 ${ }^{[12]}$, 其 $2003-2015$ 年年均 来沙量约为 $2000 \times 10^{4} \mathrm{t}$, 与本文估算的 2003-2016 年年均来沙量 $1754 \times 10^{4} \mathrm{t}$ 基本接近. 以上说明本文估算 的来沙量成果基本合理.

为评价估算的三峡水库区间人库径流量计算成果的可靠性, 根据黄陵庙站各年实测的月平均流量、坝 前水位、库容曲线以及人库控制站实测月平均流量, 结合三峡水库实际调度情况, 采用水量平衡法对三峡水 库区间月、年人库径流量进行了计算, 与本文成果比较, 月量相差均在 $12 \%$ 以内, 年量相差均在 $8 \%$ 以内 (表 4), 可以认为本文估算的区间径流量是基本可靠的.

表 4 两种方法计算的人库径流量对比

Tab.4 The runoff amount of the two methods

\begin{tabular}{|c|c|c|c|c|c|c|c|c|c|c|c|c|c|c|}
\hline & $\begin{array}{c}2003 \text { 年 } \\
6-12 \text { 月 }\end{array}$ & $\begin{array}{c}2004 \\
\text { 年 }\end{array}$ & $\begin{array}{c}2005 \\
\text { 年 }\end{array}$ & $\begin{array}{c}2006 \\
\text { 年 }\end{array}$ & $\begin{array}{c}2007 \\
\text { 年 }\end{array}$ & $\begin{array}{c}2008 \\
\text { 年 }\end{array}$ & $\begin{array}{c}2009 \\
\text { 年 }\end{array}$ & $\begin{array}{c}2010 \\
\text { 年 }\end{array}$ & $\begin{array}{c}2011 \\
\text { 年 }\end{array}$ & $\begin{array}{c}2012 \\
\text { 年 }\end{array}$ & $\begin{array}{c}2013 \\
\text { 年 }\end{array}$ & $\begin{array}{c}2014 \\
\text { 年 }\end{array}$ & $\begin{array}{c}2015 \\
\text { 年 }\end{array}$ & $\begin{array}{c}2016 \\
\text { 年 }\end{array}$ \\
\hline $\begin{array}{l}\text { 本文方法/ } \\
\left(\times 10^{8} \mathrm{~m}^{3}\right)\end{array}$ & 177 & 229 & 293 & 175 & 338 & 365 & 353 & 316 & 376 & 477 & 350 & 616 & 459 & 539 \\
\hline $\begin{array}{c}\text { 水量平衡法/ } \\
\left(\times 10^{8} \mathrm{~m}^{3}\right)\end{array}$ & 191 & 227 & 294 & 164 & 341 & 375 & 355 & 313 & 376 & 467 & 347 & 599 & 482 & 521 \\
\hline 相差/\% & 7.33 & -0.88 & 0.34 & -6.71 & 0.88 & 2.67 & 0.56 & -0.96 & 0 & -2.14 & -0.86 & -2.84 & 4.77 & -3.45 \\
\hline
\end{tabular}

\section{2 水库排沙效果分析}

3.2.1 不同蓄水阶段排沙比变化 据统计, 在考虑区间来沙情况下 (以下除特别说明外, 排沙比成果均考虑 了区间来沙情况), 围堰蓄水期, 三峡水库平均排沙比为 $34.1 \%$; 初期蓄水期为 $17.0 \% ; 175 \mathrm{~m}$ 试验性蓄水期 为 $15.4 \%$ (表 5). 总体看, 随着坝前水位的抬高, 三峡水库排沙效果有所减弱.

2003 年 6 月 -2016 年 12 月,考虑区间来沙的平均排沙比为 $21.6 \%$, 不考虑区间来沙的排沙比为 $24.1 \%$, 前者的排沙比较后者偏小 $10.4 \%$. 2013-2016 年长江上游来沙大幅减少, 考虑区间来沙的排沙比为 $16.6 \%$, 
不考虑区间来沙的排沙比为 $22.0 \%$, 前者的排沙比较后者偏小 $24.5 \%$ (表 5 ). 说明在计算三峡水库排沙比 时,考虑三峡水库区间来沙是非常必要的.

表 5 三峡水库进出库泥沙与排沙比

Tab.5 Sediment and sediment delivery ratio in the Three Gorges Reservoir

\begin{tabular}{|c|c|c|c|c|c|}
\hline \multirow{2}{*}{ 时段 } & \multirow{2}{*}{$\begin{array}{c}\text { 出库沙量/ } \\
\left(\times 10^{4} \mathrm{t}\right)\end{array}$} & \multicolumn{2}{|c|}{ 考虑区间来沙 } & \multicolumn{2}{|c|}{ 不考虑区间来沙 } \\
\hline & & 人库沙量/ $\left(\times 10^{4} \mathrm{t}\right)$ & 排沙比 $/ \%$ & 人库沙量/ $\left(\times 10^{4} \mathrm{t}\right)$ & 排沙比/\% \\
\hline 2003 年 6 月- 2006 年 8 月 & 25882 & 75831 & 34.1 & 70050 & 36.9 \\
\hline 2006 年 9 月一 2008 年 9 月 & 8311 & 48908 & 17.0 & 44357 & 18.7 \\
\hline 2008 年 10 月 -2012 年 12 月 & 12180 & 82119 & 14.8 & 75736 & 16.0 \\
\hline 2013 年 1 月 -2016 年 12 月 & 5639 & 33797 & 16.6 & 25660 & 22.0 \\
\hline 2008 年 10 月－2016 年 12 月 & 17819 & 115916 & 15.4 & 101396 & 17.6 \\
\hline 2003 年 6 月 -2016 年 12 月 & 52011 & 240655 & 21.6 & 215803 & 24.1 \\
\hline
\end{tabular}

3.2 .2 排沙比年内变化 三峡水库人库泥沙主要集中在汛期. 由于水库采用 “蓄清排浑”方式运行, 因此水库 汛期的排沙能力一般大于枯季(表 6). 但 2013 年以后, 主汛期 7-9 月平均排沙比为 17\%, 枯季 11-12 月和 1-4 月排沙比为 25\% , 出现了枯季排沙比大于汛期的现象. 由于排沙比是个相对数值, 非汛期排沙比大于汛 期, 并不代表三峡水库非汛期的排沙量就大于汛期, 三峡水库仍然是汛期的排沙量和淤积量远大于非汛期. 经统计, 2013-2016 年三峡水库汛期的排沙量和淤积量分别为 $5475 \times 10^{4}$ 和 $26940 \times 10^{4} \mathrm{t}$, 非汛期的排沙量和 淤积量分别为 $173 \times 10^{4}$ 和 $1209 \times 10^{4} \mathrm{t}$.

表 6 三峡水库不同时期月平均排沙比 ( \% )

Tab.6 Average sediment delivery ratio (\%) of the Three Gorges Reservoir in different periods

\begin{tabular}{|c|c|c|c|c|c|c|c|c|c|c|c|c|c|c|}
\hline 时段 & 1 月 & 2 月 & 3 月 & 4 月 & 5 月 & 6 月 & 7 月 & 8 月 & 9月 & 10 月 & 11 月 & 12 月 & $7-9$ 月 & $11-12 、 1-4$ 月 \\
\hline 2003 年 6 月－ 2006 年 8 月 & 10 & 13 & 14 & 5 & 5 & 12 & 32 & 39 & 52 & 19 & 13 & 13 & 41 & 11 \\
\hline 2006 年 9 月 -2008 年 9 月 & 8 & 8 & 4 & 3 & 2 & 6 & 14 & 32 & 16 & 3 & 7 & 6 & 21 & 6 \\
\hline 2008 年 10 月一 2012 年 12 月 & 7 & 16 & 12 & 9 & 4 & 4 & 18 & 24 & 7 & 3 & 2 & 8 & 16 & 9 \\
\hline 2013 年 1 月一 2016 年 12 月 & 37 & 38 & 13 & 5 & 7 & 7 & 24 & 15 & 11 & 10 & 26 & 32 & 17 & 25 \\
\hline 2008 年 10 月－ 2016 年 12 月 & 14 & 22 & 13 & 6 & 6 & 5 & 20 & 22 & 8 & 4 & 4 & 13 & 17 & 12 \\
\hline
\end{tabular}

3.2 .3 不同粒径排沙比变化 三峡水库区间来沙未测颗粒级配,假定泥沙级配与人库控制级配相同. 将三峡 人库悬移质泥沙按粒径大小分为 $\mathrm{d} \leqslant 0.062 \mathrm{~mm} 、 0.062 \mathrm{~mm}<\mathrm{d} \leqslant 0.125 \mathrm{~mm} 、 \mathrm{~d}>0.125 \mathrm{~mm} 3$ 组, 分别统计进、出库 输沙量和排沙比 (表 7). 可以看出, 由于粗颗粒泥沙在库区较细颗粒泥沙容易沉积, 故细颗粒泥沙的排沙比 一般大于粗颗粒泥沙.

表 7 三峡水库不同粒径组排沙比

Tab.7 Sediment delivery ratio of different sediment size groups

\begin{tabular}{|c|c|c|c|c|c|c|c|c|c|}
\hline \multirow[b]{2}{*}{ 时期 } & \multicolumn{3}{|c|}{$\mathrm{d} \leqslant 0.062 \mathrm{~mm}$} & \multicolumn{3}{|c|}{$0.062 \mathrm{~mm}<\mathrm{d} \leqslant 0.125 \mathrm{~mm}$} & \multicolumn{3}{|c|}{$\mathrm{d}>0.125 \mathrm{~mm}$} \\
\hline & $\begin{array}{c}\text { 人库沙量 } \\
\left(\times 10^{4} \mathrm{t}\right)\end{array}$ & $\begin{array}{c}\text { 出库沙量/ } \\
\left(\times 10^{4} \mathrm{t}\right)\end{array}$ & $\begin{array}{c}\text { 排沙比/ } \\
\%\end{array}$ & $\begin{array}{r}\text { 人库沙量 } \\
\left(\times 10^{4} \mathrm{t}\right)\end{array}$ & $\begin{array}{c}\text { 出库沙量/ } \\
\left(\times 10^{4} \mathrm{t}\right)\end{array}$ & $\begin{array}{c}\text { 排沙比/ } \\
\%\end{array}$ & $\begin{array}{c}\text { 人库沙量/ } \\
\left(\times 10^{4} \mathrm{t}\right)\end{array}$ & $\begin{array}{c}\text { 出库沙量/ } \\
\left(\times 10^{4} \mathrm{t}\right)\end{array}$ & $\begin{array}{c}\text { 排沙比/ } \\
\%\end{array}$ \\
\hline 围堰蓄水期 & 67636 & 24216 & 35.8 & 4136 & 400 & 9.7 & 4060 & 1269 & 31.3 \\
\hline 初期运行期 & 42577 & 8183 & 19.2 & 3331 & 50 & 1.5 & 3000 & 80 & 2.7 \\
\hline 试验性蓄水期 & 102200 & 17313 & 16.9 & 7110 & 351 & 4.9 & 6606 & 160 & 2.4 \\
\hline 三峡蓄水至 2016 年底 & 212406 & 49701 & 23.4 & 14581 & 800 & 5.5 & 13668 & 1510 & 11.1 \\
\hline
\end{tabular}

\section{3 排沙比影响因素分析}

3.3.1 主要影响因素分析 影响水库排沙因素主要有 3 方面: 来水来沙情况 (人库流量 $Q$ 、人库含沙量 $S$ 、来 
沙级配等)、库区地形、运行条件 (坝前水位). 对于特定水库, 排沙比 $\eta$ 的大小主要与来水来沙特性和运行 条件等密切相关 ${ }^{[13]}$. 韩其为 ${ }^{[14]}$ 根据悬移质不平衡输沙原理, 导出了水库排沙比与 $V / Q$ 呈负相关关系, 其公 式为:

$$
\eta=\frac{1}{\left(1+\frac{1}{t_{k}} \cdot \frac{V}{Q}\right)^{2}}
$$

式中, $t_{k}$ 为充水时间, $t_{k}=L / V_{k} ; V_{k}$ 为水流速度; $L$ 为河长; $V$ 为库容. 对于同一水库, 当考虑长时段排沙时, $t_{k}$ 为 常数, 故排沙比与 $V / Q$ 为单值关系.

根据三峡水库蓄水以来 $2003-2016$ 年的各月平均人库 流量、坝前水位、排沙比等资料, 点绘了排沙比与 $V / Q$ 的关系 图 (本文 $Q$ 的单位为 $\mathrm{m}^{3} / \mathrm{s}, V$ 的单位为 $\mathrm{m}^{3}$,下同), 其中库容根 据坝前水位在库容曲线查算. 由图 3 可见,三峡水库月排沙比 与 $V / Q$ 的关系大致呈 “V”形变化. 以 $V / Q=170 \times 10^{4} \mathrm{~s}$ 为界分 为左右两部分, 从时间看, 左边部分为汛期点群, 右边部分为 枯季点群. 当汛期 $V / Q \leqslant 170 \times 10^{4} \mathrm{~s}$ 时, 排沙比 $\eta$ 与 $V / Q$ 呈负 相关, 表明三峡水库汛期排沙比基本遵循韩其为公式的变化 规律, 但枯季 $V / Q>170 \times 10^{4} \mathrm{~s}$ 时, 排沙比与 $V / Q$ 呈正相关, 与韩其为公式相悖. 另从图 3 看出, 当 $V / Q=170 \times 10^{4} \mathrm{~s}$ 时, 三峡水库的排沙比出现最小值, $\eta_{\min }$ 约为 $3.5 \%$, 这种情况对三 峡水库排沙是最不利的. 为减少库区泥沙淤积, 在水库调度 时, 建议根据上游人库来水情况, 合理调节坝前水位, 尽量避 免或缩短出现此种情况的时间.

为进一步分析影响水库排沙比的主要影响因素及影响程 度, 按 $V / Q<170 \times 10^{4} \mathrm{~s}$ 和 $V / Q>170 \times 10^{4} \mathrm{~s}$ 将资料分成两个系

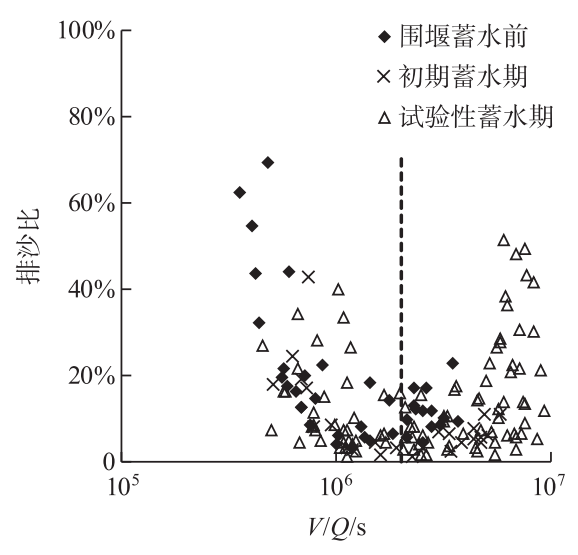

图 3 三峡水库月排沙比与 $V / Q$ 的关系 Fig.3 Relation of $V / Q$ and mouths' sediment delivery ratio in the Three Gorges Reservoir 列进行分析.

1) $V / Q<170 \times 10^{4} \mathrm{~s}$

由图 4 可见, 人库流量与排沙比呈正相关关系, 且随人库流量的增大, 点群离散程度增加; 库容与排沙 比关系较为散乱, 相同库容条件下排沙比变化较大, 但总体上随着库容增加, 排沙比有所降低: 人库含沙量 与排沙比关系点分布也较散乱, 但大致趋势是随着人库含沙量的增加, 排沙比略有增加. 总体上看, 汛期排 沙比与人库流量、库容、含沙量虽有一定关系, 但相关性较弱. 参数 $V / Q$ 综合了库容和人库流量两个因素, 表 征了人库洪水在水库中滞留时间的长短, 洪水在水库中滞留的时间越长, 越不利于排沙. 从图 $4 \mathrm{D}$ 可以看出, 排沙比与 $V / Q$ 的点群集中度明显好于前三者, 经幂函数拟合, 相关系数 $R^{2}=0.65$, 其关系式为:

$$
\eta=3 \times 10^{10}\left(\frac{V}{Q}\right)^{-1.9}
$$

2) $V / Q>170 \times 10^{4} \mathrm{~s}$

从图 5 可以看出, 排沙比与人库流量、库容、 $V / Q$ 的关系相关性较差, 说明三峡水库枯季人库流量、库容 及 $V / Q$ 不是引起排沙比变化的主要原因. 非汛期排沙比与含沙量的相关系数 $R^{2}$ 达 0.82 , 说明非汛期排沙比 与含沙量关系密切, 建立了非汛期排沙比与含沙量的关系:

$$
\eta=0.00467 S^{-0.944}
$$

3.3.2 排沙比经验公式计算值与实测值对比分析 根据公式(10)、(11) 分别计算了三峡蓄水以来的各月排 沙比, 与实测成果对比见图 6 , 可见各月排沙比计算值与实测值较好地分布在 $45^{\circ}$ 线两侧. 为评价计算效果, 分别统计了绝对误差小于 $20 \% 、 30 \% 、 50 \%$ 的点数占总点数的百分比. 经统计, 绝对误差小于 $20 \%$ 的点数占 总点数的 $49 \%$, 绝对误差小于 $30 \%$ 点数占总点数的 $69 \%$, 绝对误差小于 $50 \%$ 的点数占总点数的 $81 \%$, 说明排 沙比计算式相关性较好. 

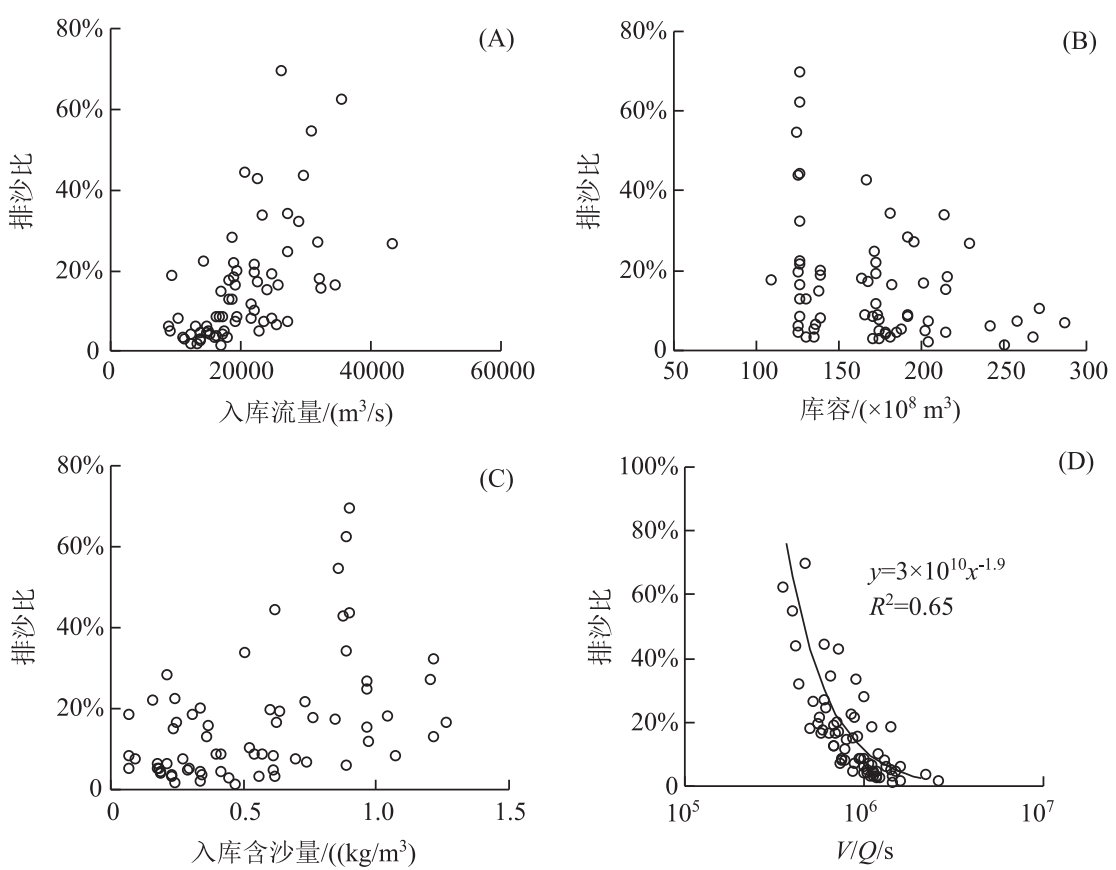

图 4 汛期排沙比与人库流量、库容、含沙量及 $V / Q$ 的关系

Fig.4 Relation of sediment delivery ratio and storage flow, reservoir capacity, sediment concentration and $V / Q$ during the flood season
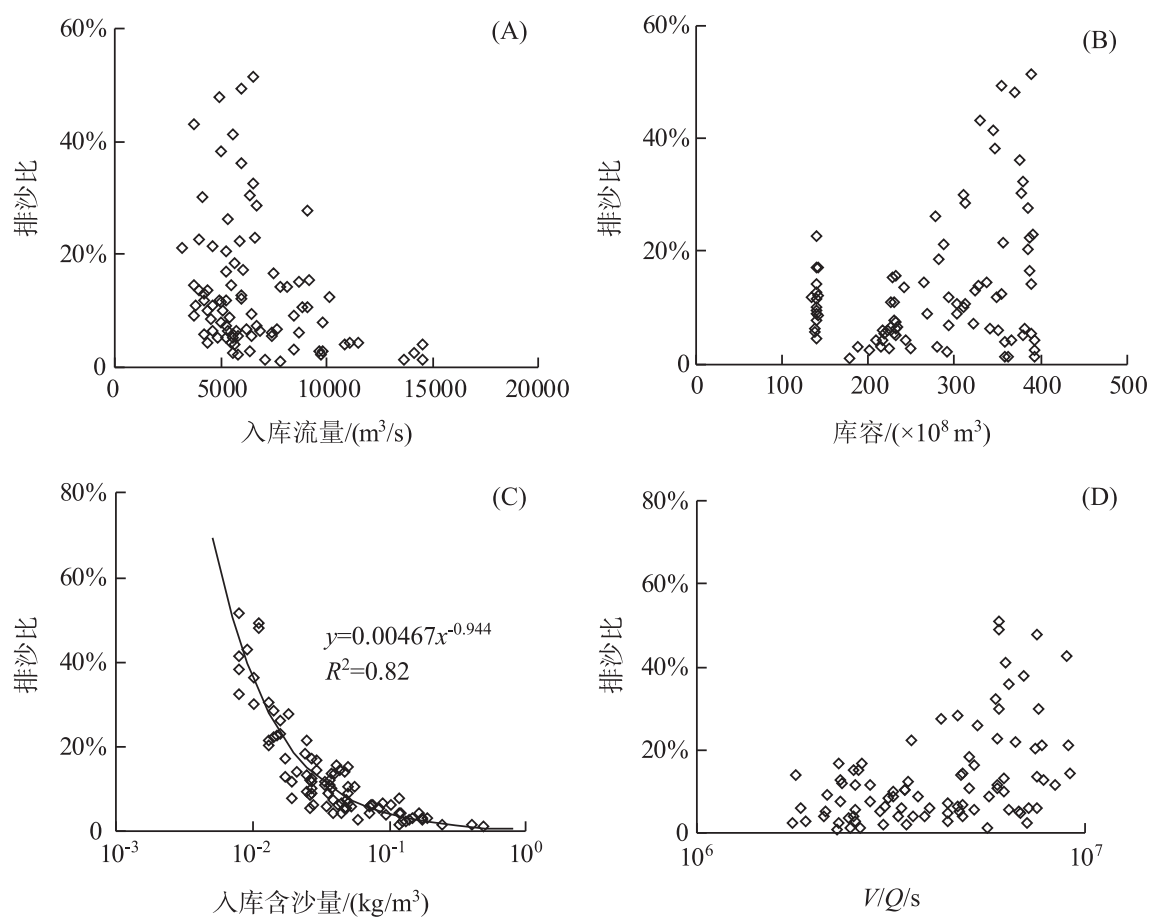

图 5 非汛期排沙比与人库流量、库容、含沙量及 $V / Q$ 的关系

Fig.5 Relation of sediment delivery ratio and storage flow, reservoir capacity, sediment concentration and $V / Q$ during the dry season 


\section{4 结论}

基于三峡进出库控制站和区间水文站实测水文资 料,在估算三峡水库区间月、年来沙量的基础上,分析 了三峡水库排沙比年际、年内变化特征和影响排沙比 的主要因素,得出以下认识:

1)三峡水库蓄水运用以来,三峡水库区间年均来 沙量约为 $1775 \times 10^{4} \mathrm{t}$, 占总人库沙量的 $10.3 \%$, 随着长 江上游来沙的减少, 区间来沙占比增大, 其中 $2013-$ 2016 年来沙量占总人库沙量的 $26.9 \%$, 在计算三峡水 库排沙比时,三峡水库区间来沙不应忽视.

2) 三峡水库蓄水运用以来, 三峡总人库悬移质泥 沙 $240655 \times 10^{4} \mathrm{t}$, 出库悬移质泥沙 $52011 \times 10^{4} \mathrm{t}$, 平均排

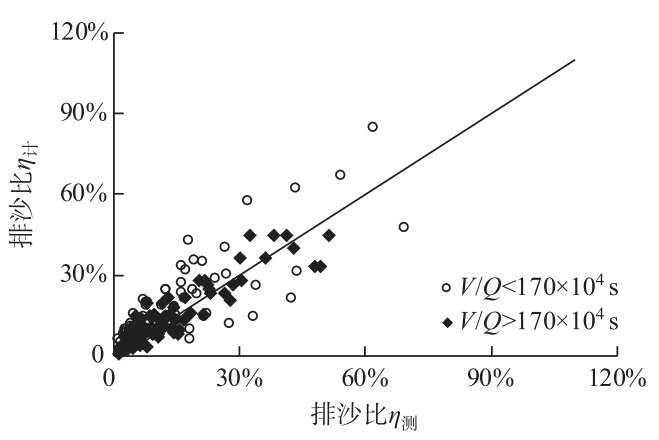

图 6 排沙比计算值与实测值对比

Fig.6 Comparison of calculated and measured values of sediment delivery ratio 沙比为 $21.6 \%$, 其中粒径 $\mathrm{d} \leqslant 0.062 \mathrm{~mm}$ 的细颗粒泥沙排 沙比为 $23.4 \%$, 粒径 $0.062 \mathrm{~mm}<\mathrm{d} \leqslant 0.125 \mathrm{~mm}$ 和 $\mathrm{d}>0.125 \mathrm{~mm}$ 的中粗沙排沙比分别为 $5.5 \%$ 和 $11.1 \%$.

$3)$ 分析表明,汛期三峡排沙比主要与 $V / Q$ 有关,并与 $V / Q$ 呈反比; 但非汛期随着含沙量的减少,三峡排 沙比逐渐增大.

4) 当 $V / Q=170 \times 10^{4} \mathrm{~s}$ 时,三峡水库的排沙比约为 $3.5 \%$, 此种情况对三峡水库排沙是最不利的. 为减少 库区泥沙淤积, 在水库调度时, 应结合来水情况合理调节坝前水位, 尽量避免或缩短此种情况的出现.

5) 本文采用水文学方法对三峡水库区间月、年来沙量进行估算，由于三峡水库区间实测泥沙资料较少， 产流产沙条件复杂, 还有待今后采用多种技术手段进一步分析比较,以检验成果的合理性.

\section{5 参考文献}

[ 1 ] Nilsson C, Reidy CA, Dynesius M et al. Fragmentation and flow regulation of the world's large river systems. Science, 2005, (308) : 405-408.

[ 2 ] NY Yong. The state and the perspective of the direct sedimental removal methods from reservoir. International Journal of Sediment Research, 1992, 7(2): 99-116.

[ 3 ] Zhou JJ ed. Schemes of sediment management proposed for the Three Gorges Project, 9th International Symposium on River Sedimentation. Beijing: Tsinghua University Press, 2004: 250-257.

[ 4 ] Yangtze River Water Resource Commission ed. Preliminary design report of the Three Gorges Hydro Complex Project. Wuhan: Yangtze River Resource Commission, 1992. [ 长江水利委员会. 长江三峡水利枢纽初步设计报告. 武汉: 长江水 利委员会, 1992.]

[ 5 ] State Council Three Gorges Project Construction Committee Executive Office Sediment Export Group, China Three Gorges Project Corporation Sediment Experts Group eds. Sediment research of the Three Gorges Project(1996-2000, volume 5). Beijing: Intellectual Property Right Press, 2002: 99-140. [ 国务院三峡工程建设委员会办公室泥沙专家组, 中国长 江三峡工程开发总公司三峡工程泥沙专家组. 长江三峡工程泥沙问题研究: 第 5 卷. 北京: 知识版权出版社, 2002: 99-140.]

[ 6 ] State Council Three Gorges Project Construction Committee Executive Office Sediment Export Group, China Three Gorges Project Corporation Sediment Experts Group eds. Sediment research of the Three Gorges Project(2001-2005, volume 2). Beijing: Intellectual Property Right Press, 2008: 1-38. [国务院三峡工程建设委员会办公室泥沙专家组, 中国长江 三峡工程开发总公司三峡工程泥沙专家组. 长江三峡工程泥沙问题研究: 第二卷. 北京: 知识版权出版社, 2008 : 1-38.]

[ 7 ] Chen GY, Yuan J, Xu QX. On sediment diversion ratio after the impoundment of the Three Gorges Project. Advances in Water Science, 2013, (23) : 355-362. [陈桂亚, 袁晶, 许全喜. 三峡水库蓄水运用以来水库排沙效果. 水科学进展, 2013, (23) : 355-362.]

[ 8 ] Yang SL, Milliman D, Xu KH et al. Downstream sedimentary and geomorphic impacts of the Three Gorges Dam on the 
Yangtze River. Earth-Science Review, 2014, 138: 469-486.

[ 9 ] Huang RY, Tan GM, Fan BL. Sediment delivery ratio of three gorges reservoir in flood events after its impoundment. Journal of Hydroelectric Engineering, 2013，(3)：129-133. [黄仁勇, 谈广鸣, 范北林. 三峡水库蓄水运用后汛期洪水排 沙比初步研究.水力发电学报, 2013, (3): 129-133.]

[10] Dong ZD, Hu HH, Ji ZW et al. Response of sediment excluding ratio to incoming flow and sediment in the Three Gorges Reservoir. Journal of Sediment Research, 2017, (6): 16-21. [ 董占地, 胡海华, 吉祖稳等. 三峡水库排沙比对来水来 沙的响应. 泥沙研究, 2017, (6): 16-21.]

[11] Changjiang River Scientific Research Institute ed. Study on erosion and sediment yield in the slope of Three Gorges Reservoir, 2013. [ 长江科学院. 三峡水库区间坡面侵蚀产沙及调控研究, 2013.]

[12] Yangtze River Water Resource Commission ed. Report on the analysis of the sediment discharge in the Three Gorges Reservoir, 2016. [ 长江水利委员会水文局. 三峡水库区间来沙量分析研究报告, 2016.]

[13] Garg V, Jothiprakash V. Modeling the time variation of reservoir trap efficiency. Journal of Hydrological Engineering, 2010, 15(12) : 1001-1015.

[14] Han QW ed. Reservoir deposition. Beijing: Science Press, 2003: 260-263. [ 韩其为. 水库淤积. 北京: 科学出版社, 2003 : 260-263. ] 